\title{
Biospecimen Retained and/or Contains DNA Indicator
}

National Cancer Institute

\section{Source}

National Cancer Institute. Biospecimen Retained and/or Contains DNA Indicator. NCI

Thesaurus. Code C126058.

An indication as to whether biospecimens have been retained and/or whether those retained biospecimens contain DNA. 